\title{
Competitiveness of the EU Beef Sector - a Case Study
}

\author{
Z. Smeets Kristkova ${ }^{1}$, J. M. García Alvaréz Coque ${ }^{2}$ \\ ${ }^{1}$ Faculty of Economics and Management, Czech University of Life Sciences Prague, Czech Republic \\ ${ }^{2}$ Universitat Politecnica de Valencia, Spain
}

\begin{abstract}
Anotace
V tomto přispěvku je analyzována konkurenceschopnost sektoru hověziho masa v EU za použiti hodnotového řetězce. Následovně je diskutován dopad vnějších faktorů jako je Společná zemědělská politika EU a zahraniční obchodní politika za účelem vytvoření doporučení. Ukazuje se, že investice do spolupracujících nabídkových řetězců může zlepšit znevýhodněnou pozici výrobců hovězího masa, kteří mají nejmenší sílu v nabidkovém řetězci. Dále, oblast vědy a výzkumu poskytuje řadu př́ležitostí, které by měly být více využity, jako jsou zlepšeni v logistice a vytvoření lépe zaměřeného systému kvality masa. Hlavní ohrožení vyplývají z potenciálních dohod volného obchodu, klimatické změny a konkurence výroby hovězího masa s jinými zemědělskými komoditami. Lepši zaměření SZP a environmentální aspekty jsou navrženy pro udržení konkurenceschopnosti evropských producentů hovězího masa.
\end{abstract}

\section{Klíčová slova}

Hovězí a telecí maso, exporty, konkurenceschopnost, Evropská unie, hodnotový řetězec, Společná zemědělská politika, liberalizace obchodu.

\begin{abstract}
In this study, the elements of competitiveness of the EU beef sector are assessed using the value chain approach. Consequently, the impact of the external factors represented by domestic policy and foreign trade policy is discussed, with the aim of deriving recommendations for policy makers. It is shown that investing in collaborative supply chains can improve the disadvantaged position of beef producers, which have the least power in the supply chain. Furthermore, the domains of science and innovation provide several opportunities that could be further explored, namely improving the logistics of the supply chain and developing more tailored quality systems. The main threats stem from potential free trade agreements, climate change and the internal competition between other agricultural crops. Better targeting of the CAP and environmental aspects are suggested to maintain the competitiveness of European beef producers.
\end{abstract}

\section{Key words}

Beef and veal, exports, competitiveness, European Union, value chain, Common Agricultural Policy, trade liberalization.

\section{Introduction}

Livestock farming systems offer numerous benefits. Besides producing foods rich in protein and with high nutritional value, they also provide environmental and social benefits to society, since they preserve ecosystem services and provide employment in marginal areas. On the other hand, there are also negative aspects resulting from livestock farming. It is well established that among the major food items, beef carries the highest environmental burden (Nguyen et al., 2010) and has a significant contribution to climate change.
The conditions for beef production in the European Union are highly variable due to the variety of climates and landscapes. However, the prospects of beef production in the EU are not driven only by biophysical factors, but increasingly by the effects of globalization. On one hand, increased demand for beef in developing countries could stimulate production of beef; on the other hand, climate change concerns could act against it. European producers of beef are also facing increasing market competition due to continuous liberalization efforts on the part of WTO, as well as new free trade agreements that will further 
open European markets to important players such as the United States, Canada and the Mercosur countries. To turn these potential threats into opportunities, strategies for increasing competitiveness are necessary.

In relation to this, the paper deals with the following objectives: i) to analyse the position of EU beef sector within the increasingly globalized world and ii) to identify major factors of competitiveness of the EU beef sector taking into account both internal and external pressures.

In this study, the elements of competitiveness of the EU beef sector are assessed using the value chain approach ${ }^{1}$. Consequently, the impact of the external factors represented by domestic policy and foreign trade policy is discussed, with the aim of deriving recommendations for policy makers. The paper is structured as follows: at first, a descriptive analysis of the beef sector is provided. Chapter 3 contains results of the value chain analysis and discussion and chapter four concludes.

Characteristics of the global and EU beef markets

\section{Global trends in trade, production and consumption of beef}

Total global production and consumption of beef nearly doubled between the decades of the 1960s (29.3 million tons) and 2010s (58 million tons), and worldwide exports grew in volume by $300 \%$. Nowadays, about $15 \%$ of world production is exported, which is double the rate in the 1960 s and underlines the rising importance of foreign trade on beef markets.

The United States is the largest producer of beef in the world, with levels of production exceeding

\footnotetext{
1 The results of this paper served for the elaboration of the study prepared for the European Parliament (2014): EU-Member States in Agri-Food World Markets: Current Competitive Positions and Perspectives.
}

10 million tons a year (Table 1). However, the share of US production is declining slightly as other countries become more involved in producing beef. This refers mainly to Brazil, which nowadays produces almost 8 million tons of beef and has replaced the EU in the second position. The European Union has recently moved into the third position with a production of 7.7 million tons, which represents a decline from the year 2000 in the share of global production from $16 \%$ to $12 \%$. China and India are also noteworthy global producers of beef. Although China produces $10 \%$ of the world's production, this is not sufficient to cover domestic consumption, making China a net importer of beef. India, on the other hand, due to the constraints on beef consumption in the domestic diet, is able to produce a surplus, which makes India an increasingly important worldwide net exporter.

The evolution of production trends from a dynamic perspective, including projections until 2020, is depicted in Figure 1. Since 2000, EU and US production has been stable at the levels of 12 and 8 million tons, respectively, with some periods of decline caused by BSE outbreaks. In Brazil, the production of beef has been sharply increasing since 1980. From 2 million tons of beef in 1980, Brazil has expanded its production to almost 10 million tons in 2013. According to FAPRI estimates, it is expected that by 2020 Brazil will be the largest producer of beef in the world, displacing the US to the second rank due to its gradual decline in production to below 12 million tons. Continuous growth in production has occurred in India and China, and it is expected to continue until 2020.

Changes in production and consumption levels are reflected in the volumes of net exports. Table 2 shows the top ten exporters in the world from 1960 until today. Argentina, Australia and New Zealand have traditionally ranked at the top as the largest net exporters of beef in the world. Whereas Australia

\begin{tabular}{|l|r|r|r|r|r|r|r|r|}
\hline \multirow{2}{*}{ Country } & \multicolumn{4}{|c|}{ Top producers of beef and veal } & \multicolumn{4}{c|}{ Top consumers of beef and veal } \\
\cline { 2 - 9 } & $\mathbf{2 0 0 0}$ & $\mathbf{\%}$ share & $\mathbf{2 0 1 3}$ & \% share & $\mathbf{2 0 0 0}$ & \% share & $\mathbf{2 0 1 3}$ & \% share \\
\hline United States & 12298 & $23 \%$ & 11702 & $20 \%$ & 12502 & $24 \%$ & 11638 & $20 \%$ \\
\hline Brazil & 6520 & $\mathbf{1 2 \%}$ & 9600 & $\mathbf{1 6 \%}$ & 6105 & $\mathbf{1 2 \%}$ & 7860 & $\mathbf{1 4 \%}$ \\
\hline European Union & 8325 & $\mathbf{1 6 \%}$ & 7690 & $\mathbf{1 3 \%}$ & 8157 & $\mathbf{1 5 \%}$ & 7780 & $\mathbf{1 4 \%}$ \\
\hline China & 5131 & $10 \%$ & 5637 & $10 \%$ & 5100 & $10 \%$ & 6007 & $11 \%$ \\
\hline India & 1525 & $3 \%$ & 3750 & $6 \%$ & 2545 & $5 \%$ & 2620 & $5 \%$ \\
\hline
\end{tabular}

Source: USDA FAS-PSD Online 2013, author's elaboration

Table 1: Top worldwide producers and consumers of beef and veal (1,000 MT CWE). 


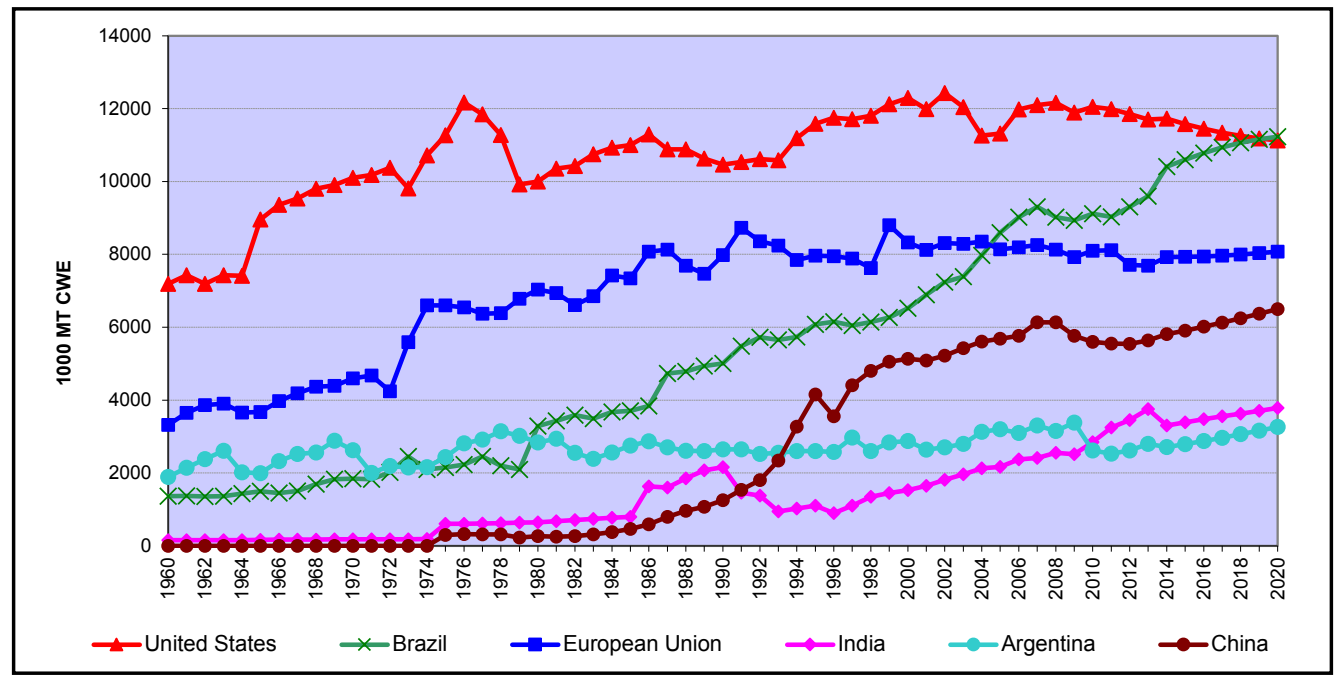

Note: Data for the EU for 1960-1993 represents production in countries included in the European Community, data for 1993-1999 represents the EU-15, and for 2000-2013 the EU-27.

Source: USDA FAS-PSD Online 2013 (1960-2012), FAPRI-ISU 2012 (2013-2020)

Figure 1: Selected worldwide producers of beef.

\begin{tabular}{|c|lr|lr|lr|lr|}
\hline Ranking & Country & av 1960 & Country & av 1980 & Country & av 2000 & Country & av 2010 \\
\hline 1 & Argentina & 577 & Australia & 809 & Brazil & 1391 & Brazil & 1506 \\
\hline 2 & Australia & 377 & New & 369 & Australia & 1356 & Australia & 1418 \\
\hline 3 & New Zealand & 160 & Argentina & 361 & India & 530 & India & 1312 \\
\hline 4 & Ireland & 100 & Ireland & 324 & New Zealand & 511 & New Zealand & 513 \\
\hline 5 & Uruguay & 93 & Brazil & 285 & Argentina & 461 & Uruguay & 352 \\
\hline 6 & Denmark & 92 & Netherlands & 209 & Uruguay & 322 & Paraguay & 256 \\
\hline 7 & France & 70 & Denmark & 158 & Canada & 292 & Argentina & 207 \\
\hline 8 & Yugoslavia & 70 & Germany & 157 & Paraguay & 141 & Belarus & 172 \\
\hline 9 & Brazil & 43 & Uruguay & 152 & Ukraine & 82 & United States & 132 \\
\hline 10 & Mexico & 35 & France & 121 & Belarus & 66 & Nicaragua & 132 \\
\hline
\end{tabular}

Note: mean 2010 is computed for $2010-2013$

Source: USDA FAS-PSD Online 2013, author's elaboration

Table 2: Top net exporters of beef and veal (1,000 MT CWE).

has managed to keep the highest rank over time, with net exports expanding from 377 thousand to 1.4 million tons ofbeef,Argentinahas seen a decline in net exports from its premium ranking in the 1960s to the tenth position, with traded volume falling to 132 thousand tons. This negative development was caused by an adverse governmental policy that applied protectionist measures on exports of beef to prevent domestic prices from rising. As a result, Argentinean farmers reduced stocks of herds and converted to soybean production. Compared to Argentina, Australia's strong competitive position is also enhanced by its disease-free status, which secures preferential access to the high-priced markets of Japan and the United States, the largest export markets for Australia (Spencer, 2014).
Since 2000, the traditional exporters of beef have faced increasing competition from Brazil and India. Currently, Brazil is the largest net exporter of beef in the world, with net exports reaching 1.5 million tons. This is supported by very favourable conditions for grass-fed beef production, given that the amount of pasture land available for cattle production reaches 171 million ha (UZEI, 2013). Furthermore, the increase in the supply of beef was also driven by significant improvements in technical efficiency that resulted in an $86 \%$ increase in the volume of beef processed in Brazil. The most important Brazilian export markets are Russia, which imports $40 \%$ of its beef from Brazil, followed by Hong Kong and Egypt. 
India has also seen a boom in beef exports, fuelled by increasing cattle herds resulting from rising consumption of dairy products, private investments in agriculture and the ability to offer lowerquality halal meat, which makes India attractive in the Southeast Asia and Middle East markets (USDA, 2014).

Table 3 presents a list of the largest net importers of beef and veal in the world. In the 1960s and 1970s, the United States was the largest net importer of beef. Since 2000, this position has been occupied by Russia, which currently imports over 1 million tons of beef. The second most significant importer of beef is Japan, which is mainly dependent on Australian exports and recently also on the United States, which is becoming an important competitor for Australia due to offerings from the food-service sector and readyto-eat businesses (USDA, 2014).

An important factor that influences the foreign trading of beef is the evolution of per capita beef consumption. There is a large gap between the OECD countries, where consumers eat around $15 \mathrm{~kg}$ of beef per year, and developing countries which consume less than $5 \mathrm{~kg}$ on average (according to OECD-FAO, 2014). Lower consumption of beef in developing countries might be a result of the generally higher price level of beef compared to other sources of protein nutrition, such as pork and poultry, which makes beef a more luxurious type of good. In many countries, consumption of beef is also driven by religion and local eating habits. In developed countries, consumption of beef per capita has been declining, which may be associated with vegetarian trends in diets, concerns about environmental sustainability, mistrust in beef consumption due to health crises and limited options for ready-to-eat alternatives (Hocquette and Chatellier, 2011).

The largest per capita consumption of beef is found in Uruguay (Figure 2), where the level exceeds $50 \mathrm{~kg}$ per year and, according to the projections,

\begin{tabular}{|c|lr|lr|lr|lr|}
\hline Ranking & Country & av 1960 & Country & av 1980 & Country & av 2000 & Country & av 2010 \\
\hline 1 & United States & 513 & United States & 738 & Russia & 880 & Russia & 1011 \\
\hline 2 & UK & 422 & Italy & 357 & Japan & 760 & Japan & 742 \\
\hline 3 & Italy & 220 & Soviet Union & 283 & United States & 618 & Korea, South & 382 \\
\hline 4 & Germany & 110 & Japan & 259 & Mexico & 363 & Hong Kong & 249 \\
\hline 5 & Spain & 66 & Russia & 252 & Korea, South & 317 & Egypt & 236 \\
\hline 6 & German DR & 59 & UK & 192 & EU & 202 & Iran & 215 \\
\hline 7 & Greece & 30 & Egypt & 144 & Egypt & 201 & Venezuela & 196 \\
\hline 8 & Switzerland & 29 & Greece & 131 & Malaysia & 144 & Chile & 184 \\
\hline 9 & Czechoslovakia & 27 & Hong Kong & 74 & Chile & 142 & Malaysia & 168 \\
\hline 10 & Chile & 24 & Saudi Arabia & 45 & Philippines & 135 & Saudi Arabia & 131 \\
\hline
\end{tabular}

Source: USDA FAS-PSD Online 2013, author's elaboration

Table 3: 10 largest net importers of beef and veal (1,000 MT CWE).

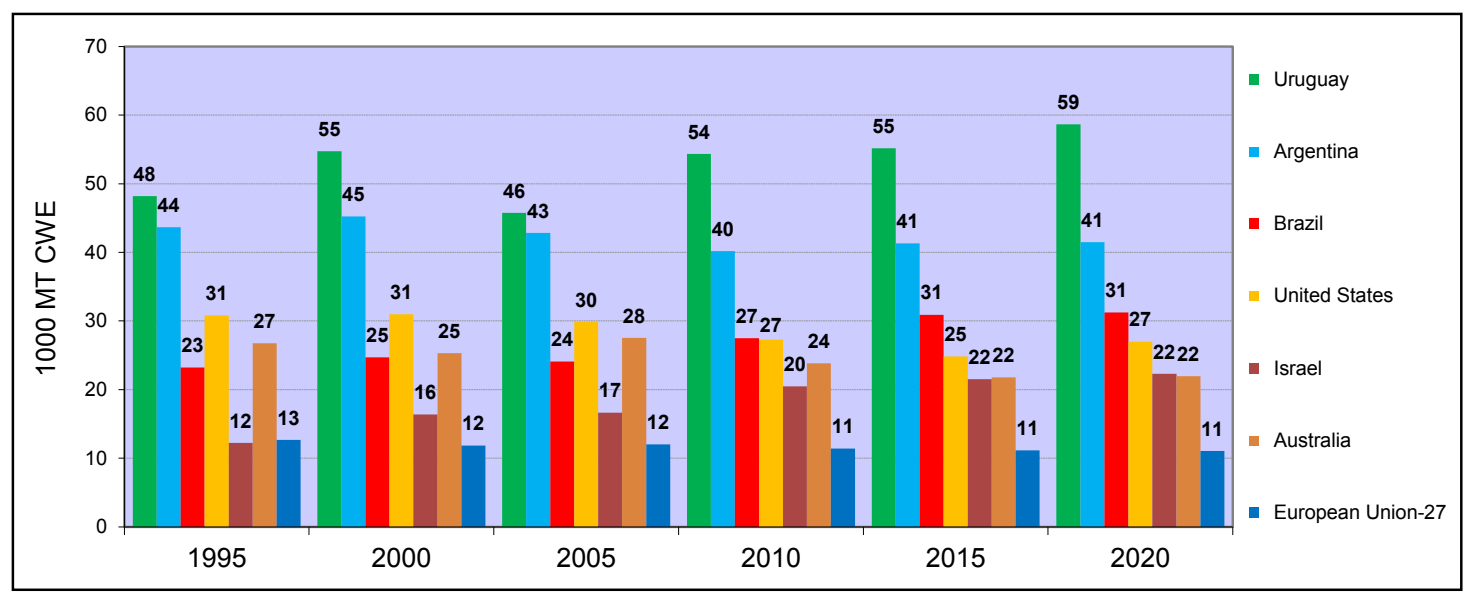

Source: OECD-FAO Agricultural Outlook

Figure 2: Projections of beef consumption per capita for the largest consumers of beef per capita. 
could further increase to $59 \mathrm{~kg}$. Even with such high per capita consumption, Uruguay is able to produce a surplus of beef, which gives it good prospects for maintaining its position among the top ten exporters in the world. The second largest per capita consumption of beef (40 kg per capita) is found in Argentina, where production recently declined due to the mentioned policy interventions. In Brazil, the third largest consumer of beef per capita, the increasing trend in consumption will limit further expansion of beef exports in the future. The United States, Israel and Australia occupy the next ranks, with consumption levels exceeding $20 \mathrm{~kg}$. The consumption of beef per capita in the European Union is considerably lower - the average European citizen consumes only $11 \mathrm{~kg}$ of beef per capita per year, which is well below the OECD average and the average for all developed economies. This is explained by the fact that other types of meat, for instance pork, are traditionally preferred in many EU countries. Being a more luxurious commodity, beef has also suffered more from the impacts of the economic crisis in the EU, resulting in the replacement of beef with less-expensive chicken meat.

\section{Characteristics of the beef sector in the European Union}

The average share of beef production in total agricultural production reaches $8.4 \%$ in the European Union, which is slightly less than the share of pork $(9.5 \%)$, but more than for cereals $(5.9 \%)$, for instance. There is considerable variance across the EU member states regarding the importance of cattle. In Ireland, beef contributes to total production by $28 \%$, whereas in Hungary, Cyprus and Romania it reaches only $2 \%$ (Figure 3 ). This is related to the conditions of beef farming in the EU. In Ireland, the UK and central France, extensive cow-calf farms can be found, whereas in Southern Europe, intensive beef fattening systems prevail.

With respect to cattle herds, $50 \%$ of all head are concentrated in France, Germany and the United Kingdom. Regarding beef production, next to France and Germany an important producer of beef is Italy, which occupies the third rank, followed by the United Kingdom and Ireland.

The structure of exports shows that most trade in beef is carried out as in the intra-European regime $(87 \%)$, and most trade is carried out in the form of fresh meat $(83 \%)$; only $17 \%$ of beef is traded in the form of live animals.

Concerning the extra-EU trade, the most important export territories for beef and veal are Russia and Turkey (Figure 4). In 2011, exports to these two territories reached almost $70 \%$ of all trade. Turkey became a significant export market for EU beef in 2010, and in 2011, exports to Turkey exceeded 160 thousand tons. However, exports to Turkey fell noticeably in 2012 due to restrictions on imports of live cattle, beef and derivative products on the part of the Turkish government. A declining trend is also seen in the case of Russia, which has reacted to the higher prices of beef in the EU as well as the depreciating currency of Latin American economies.

With respect to EU imports (Figure 5), the largest importer of beef to the European market is Brazil,

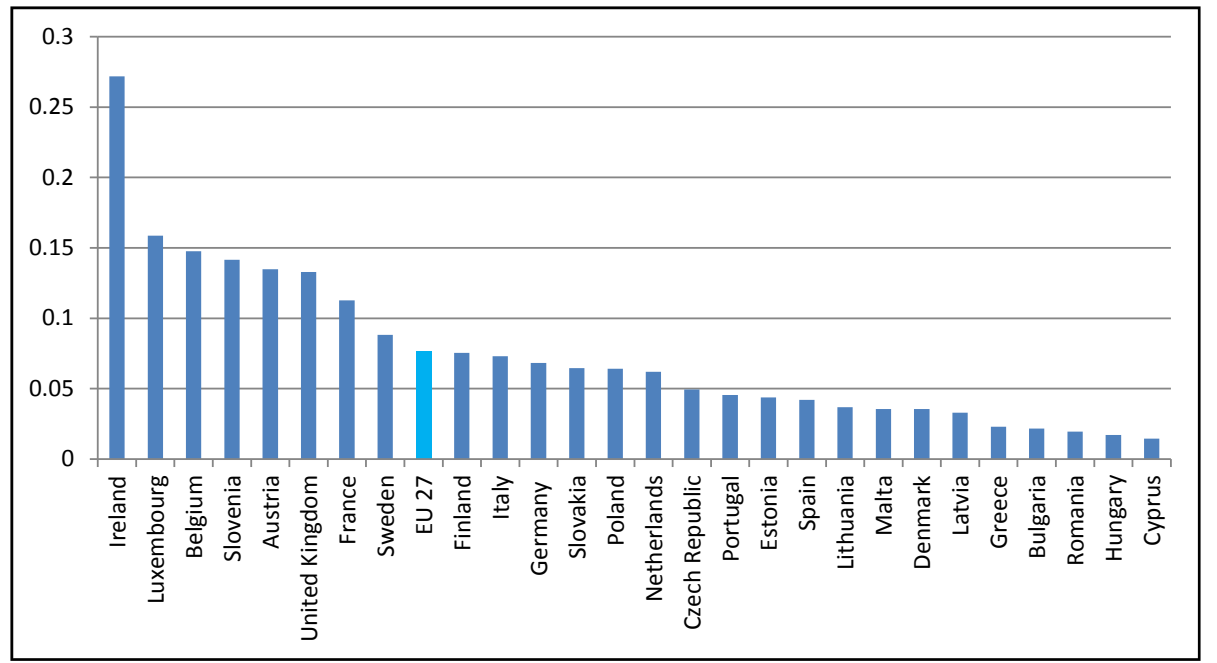

Source: Eurostat Economic Accounts for Agriculture (2013), values at constant 2005 prices

Figure 3: Share of cattle production in agricultural output in 2013. 


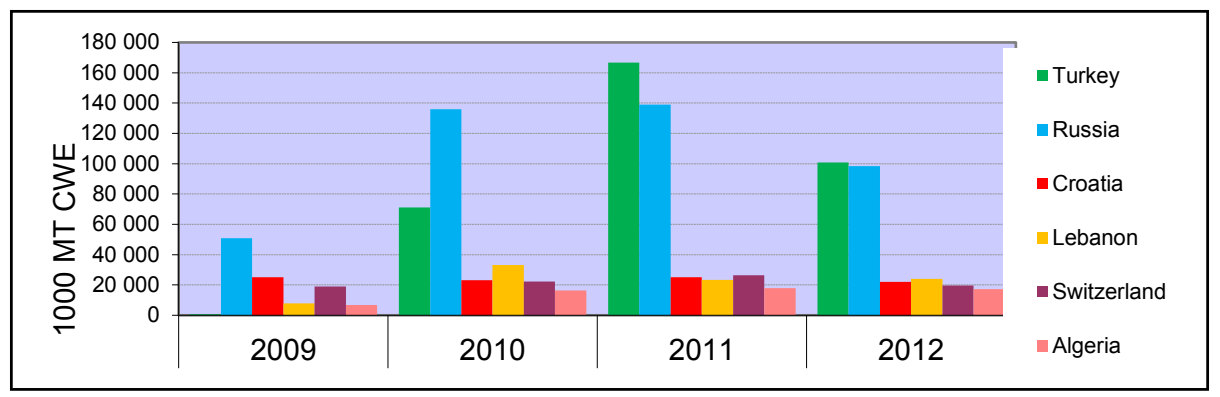

Source: European Commission (2012), cit. in UZEI Report (2013)

Figure 4: Main exporting territories for the $\mathrm{EU} \neg-27$ trade in beef and veal.

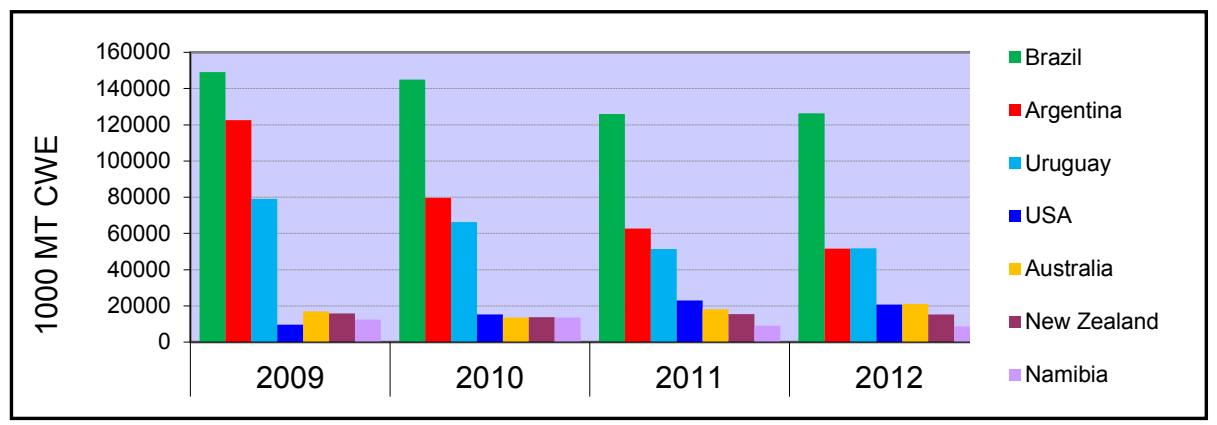

Source: European Commission (2012), cit. in UZEI Report (2013)

Figure 5: Main importing territories for the EU $\neg-27$ trade in beef and veal

which accounts for about $40 \%$ of total imports. Beef is also imported from Argentina and Uruguay, and to a lesser extent from the US and Australia. Although their beef exports to the EU have increased, Brazil has a limited ability to supply the EU, as few cattle farms are eligible to export to the European market due to the restrictions imposed on Brazil in 2007 (Only 2,000 farms in Brazil are currently authorized to export beef to the EU, down from 26,000 before the restrictions).

\section{Materials and methods}

The objective of the study is to assess the competitive position of the EU beef sector in the global market by examining the influence and scope of policies affecting competitiveness. The study contains two axes:

- From a positive point of view, the study considers the strengths and weaknesses of the sector, with reference to the beef value chain, including a thorough analysis of import-export performance.

- From a normative point of view, the study adopts the method of policy evaluation, with a view to assessing policy developments, the new EU tools for the period 2014-2020, and possible new tools in order to promote competitiveness and innovation for the beef sector.

The first part of the study assesses the competitiveness of the EU beef sector using the value chain approach based on Hofwegen et al. (2005). The following drivers of the supply chain were determined: market structure, regulation, chain coordination, logistics, quality, value added, and the costs and sustainability of the value chain. A graphical representation of the drivers in the beef supply chain is provided in Diagram 1 .

Given that the study encompasses the whole EU region, a micro-level case study would not be appropriate. Therefore, the value chain approach is elaborated using secondary data and is based on a wide range of literature sources. More specifically, various elements of the value chain are assessed, compiling evidence from individual case studies, policy-oriented reports and academic journals. Finally, a synthesis of the key aspects of competitiveness and prospects for the future is provided.

The second part of the study discusses the external drivers that affect the competitiveness of the EU beef sector. Three specific policy areas are identified as the key external drivers of competitiveness.

Finally, the EU beef sector's future prospects, 


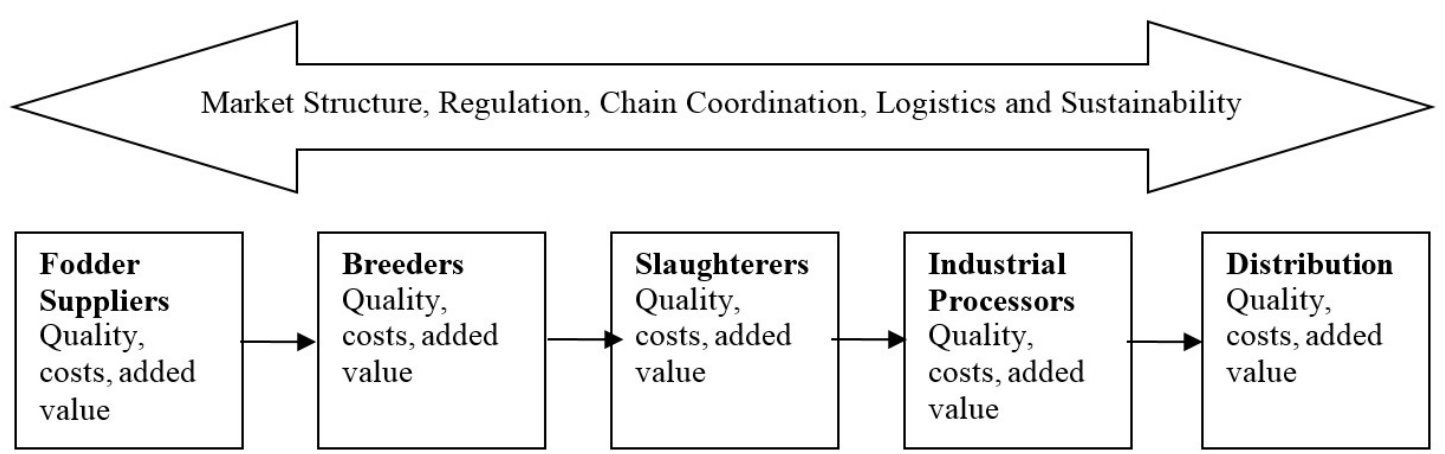

Source: author's own elaboration based on Hofwegen et al. (2005)

Scheme 1: Schematic representation of the beef supply chain and its main drivers.

classified into key opportunities and threats, are discussed.

\section{Results and discussion}

\section{Drivers of competitiveness in the beef and veal value chain}

\subsection{Market structure of the beef supply chain}

Market structure is an important external driver of competitiveness. The type of market structure consequently determines the quality of chain coordination, the distribution of value added in the chain, and the costs that are passed on to consumers.

In the European Union, there are about 2,500 farms engaged in cattle production. Figure 6 demonstrates the inequality in cattle farms in percentage terms. It can be observed that $60 \%$ of farms possess only $5 \%$ of herds, whereas $10 \%$ of farms operate with $62 \%$ of all animals.

These figures support the general observation that the producer base for beef in the EU is fragmented. Concrete examples can be given for various EU countries. In Britain, for instance, there are 63,000 individual producers, which leads to inconsistency in the composition of finished animals and creates unnecessary costs that are passed on to consumers. These factors lead to a greater price differential in beef compared to chicken (Value Chain Management Centre, 2014). Another example can be seen in Ireland, where the average herd is 18 cows per farm and the average farm size is 27.5 ha (Irish Department of Agriculture, 2014), a situation which increases costs and reduces the adoption of modern management practices. Evidence also comes from Italy, where there were 80 thousand stock farms for 2,200 slaughterhouses in 2010 (Golini and Kalchschmidt, 2011).
On the other side of the supply chain, conditions are quite the opposite. There is strong evidence that the retail environment in most EU countries is highly concentrated and heavily dominates the beef sector (Hofwegen et al., 2005). For instance, Great Britain has five major retailers (Value Chain Management Centre, 2014) and they account for $80 \%$ of beef sales (Hofwegen et al., 2005). According to Francis et al. (2003), the concentration of market power in the hands of food retailers has contributed to an unprecedented structural change in the beef sector.

Problems with imbalance in the value chain are found in non-EU countries as well. For instance, a study on supply chain performance in the Australian beef industry (Uddin, 2011) reported that producers have a much lower ability to negotiate prices in the supply chain than processors and retailers, which leads to power imbalance in the chain. The authors also found that the power of a farm significantly increases with its size.

Evidence of the weak market power of suppliers in the beef market has also been confirmed in the academic literature. For instance, in a study by Rezitis and Stavropoulos (2010), the authors examined the supply responses of the Greek beef market and found a negative asymmetric price volatility, which implies that producers have a weak market position. Rumánková (2012) analysed the price transmission mechanism in Czech meat markets. Employing the VECM model, she found imperfect competition in the form of oligopsony or oligopoly, confirming that wholesalers have a stronger position than farmers. Furthermore, she also concluded that agri-food chains can be considered demand-driven. 


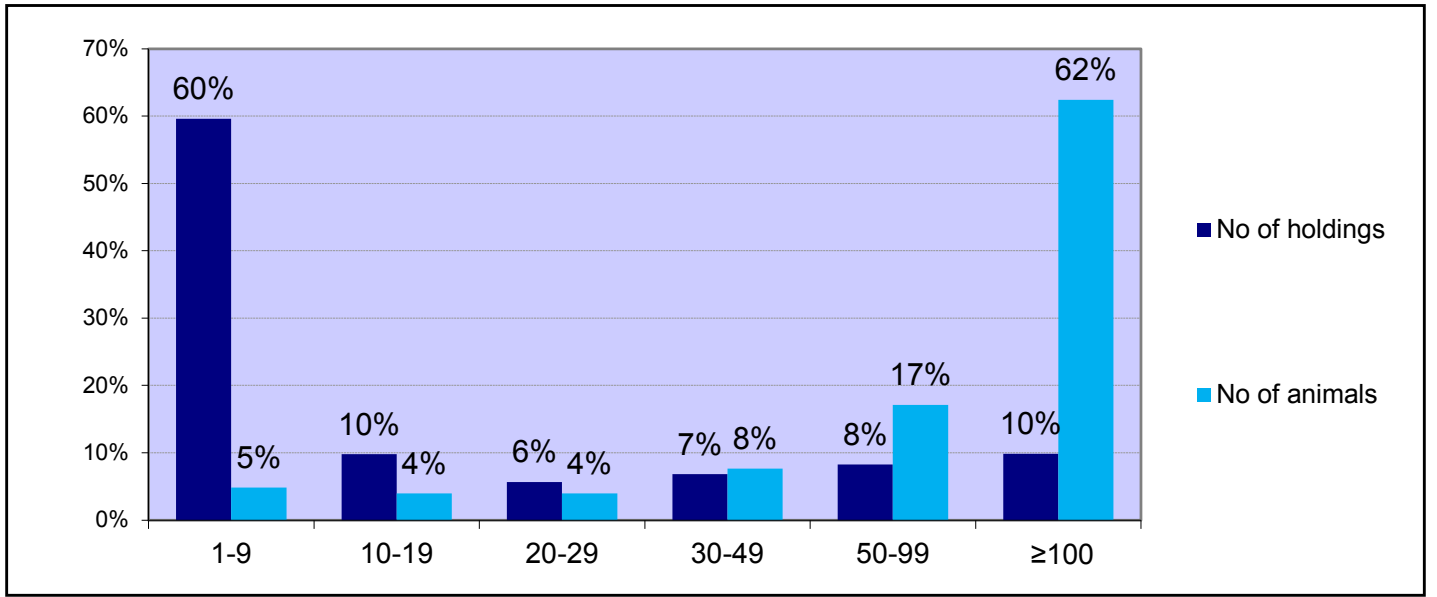

Source: European Commission (2012)

Figure 6: Structure of cattle production by herd size.

\subsection{Regulations concerning production of beef and veal}

Regulations set the boundary condition for doing business within the supply chain (Hofwegen et al., 2005). On one hand, regulation generally increases the burden on producers as well as the production costs; on the other hand, it positively promotes sustainable practices that otherwise would not be pursued, as follows from a study by Golini, Kalchschmidt (2011).

The beef sector is one of the most regulated sectors. One of the most important regulations concerning beef production is the $\boldsymbol{E} \boldsymbol{U}$ Directive on Traceability (EU Commission Regulation (EC) No. 178/2002), formulated and adopted as a consequence of the BSE scare, which highlighted deficiencies in traceability systems and in European law (Safe Food, 2008).

The Traceability Directive requires the identification and registration of bovine animals (EU Directive 1760/2000) and their movements from birth to slaughter, including a compulsory individual cattle passport that must accompany all intra-Community movements of the animals.

In addition to traceability, the European Commission also requires proper labelling standards. In 2000, the EU introduced Beef Labelling Regulation 1760/2000, which gives detailed instructions on labelling meat originating both within the EU and from third countries, as well as sold over the counter or in restaurants.

Concerning animal welfare, EU farmers must follow the general requirements of Directive 98/58/ EC, which governs the welfare of farm animals and also the legislation and codes of practice in the countries in which they are based.

In addition to the regulations obligatory for all members of the beef supply chain, farmers are also required to comply with cross-compliance rules, which can generate additional costs of production. In (Roest et al. 2008), the authors examine the impact of the Nitrate Directive and the identification and registration of bovines on the competitiveness of the EU beef sector. The calculations show that $100 \%$ compliance with both standards would increase production costs and cause a $3.7 \%$ decline in EU exports, which would mostly favour Brazil.

\subsection{Issues concerning chain coordination}

There are various arguments in favour of increasing coordination in the value chain of beef. First, as follows from market structure analysis, there is a strong imbalance between producers and the other parts of the supply chain. One way to increase the bargaining power of farmers is by creating horizontal cooperatives or vertical coordination. In this way "producers can gain power as marketers rather than sellers" (Uddin, 2011).

A study by the Canadian Value Chain Management Centre (2011) on the British beef industry revealed that, "producer-driven initiatives often have the greatest chance of succeeding over processors and retailer-led initiatives as they often focus on price ahead of other factors". One British example of a successful value chain initiative in beef is the Blade Farming model, which ensures that beef is produced according to consumer requirements, thereby benefiting all members of the entire chain. The following are important features of these 
initiatives:

* Consistency in the quality of beef is ensured by controlling the genetic content of semen (cross of Angus and Holstein), which ensures the proper carcass composition of the calf.

* Quality control ensures stable, pre-agreed prices for calf, weaner and finisher producers.

* Stability increases the efficiency of finishing, as the calves are delivered and collected in entire lots, and reduces mortality.

Second, the need for a coordinated supply chain is driven by the increased risk exposure of farmers due to the decoupling of direct payments, which are intended to increase the market orientation of farmers. According to Revoredi-Giha et al. (2008), collaborative supply chains for finished livestock may contribute to higher income stability due to stable demand and market access and less variability in carcass prices. "The outcomes of the case study showed that farmers selling through producer clubs are more satisfied than farmers selling through auctions".

Third, supply chain coordination by forming a strategic alliance through contracting or vertical integration is an efficient way to cope with high transaction costs, in which the use of a spot or open market system is inefficient. Transaction costs arise from contacting buyers and sellers and negotiation, and are stimulated by opportunistic behaviour and the asymmetry of information between buyer and seller in the supply chain. Vertical coordination can have different forms, described in Uddin, 2011. Auction and spot markets represent the lowest level of coordination, and are characterised by short-term relationships, opportunism and limited information sharing. With increasing vertical coordination, the coordination becomes managed internally and the members of the supply chain openly share information; the coordination is characterized by long-term relationships and mutual interest. The example of the Irish sector shows that coordination of the beef supply chain could be improved, as there is a perception of poor communication within the entire value chain resulting in poor market signals to producers. For Australia, it is estimated that the transaction costs of the supply chain from producer to processor to distributor, as well as retail costs, could increase by $80 \%$ in the absence of a highly coordinated supply chain.

\subsection{Role of logistics}

Within the EU-15, transport intensification, involving about 45 million transported cattle per year, contributes significantly to the stress and harm to the well-being of the animals and the accompanying environmental degradation. Therefore, there is great concern that agri-food logistics systems be designed properly in order to strengthen the economic competitiveness of stakeholders in the food supply chain, maintain the quality of food and animal welfare and mitigate the environmental impact (Gebresenbet and Bosona, 2012).

With regard to animal transport, the logistics components involve loading, transporting and unloading animals, as well as the slaughter chain. One of the largest logistical concerns is the impact of transport operations on animal welfare. Long-distance transport and poor handling increase the stress level of the animals. Loading and unloading during transport for slaughter are also indentified as very stressful activities for animals - a study carried out by Bulitta et al. (2011) showed that the heart rate of the animal increases from $80 \mathrm{bpm}$ to $136 \mathrm{bpm}$ during loading. Moreover, the increased stress exposure negatively affects meat quality, and long transport distances increase emissions.

According to Gebresenbet and Bosona (2012), there are two strategies for improving animal welfare during transport. The first strategy focuses on minimising stress-inducing factors by improving transport logistics and handling methods. The second strategy is to support small-scale or mobile abattoirs. A study performed in Sweden showed that when compared with a large-scale abattoir, a small-scale abattoir can reduce transport time and emissions by about $40 \%$. A comparable time and cost reduction can be achieved by increased coordination in the food distribution system, such as through combined loading or the optimization of vehicle fleets.

\subsection{Issues concerning beef quality}

The quality of beef is assured by a regulatory system which imposes traceability and labelling standards. On top of that, there are various optional instruments used to guarantee quality, such as the EU quality schemes PDO, PGI and TSG. However, as pointed out in Hockettet and Chatellier (2011), consumers may become overwhelmed in the presence of so many official quality signs. As many European consumers are also price sensitive, the high price of a product associated with a quality label may reduce the demand. What is more, the trust of consumers may not be sufficiently 
secured by the quality labels. Particularly in the case of beef, food safety concerns have been important. As a result of the BSE crisis in 2000, consumption decreased substantially, for instance by $40 \%$ in France, $60 \%$ in Germany and $42 \%$ in Italy (Angulo and Gil, 2007). In order to restore the damaged trust of consumers, traceability and labelling was introduced, and a larger emphasis was placed on Protected Designation of Origin. The results of a Spanish study on the perception of risk associated with the safety of beef revealed that only one in four respondents is willing to pay a premium for the indication of traceability, because they perceive beef safety as a given.

From the consumer's point of view, the strongest quality attributes for beef are taste, tenderness, juiciness, leanness and healthiness (Verbeke et al., 2010). There is a general consensus that the most advanced system for guaranteeing the quality of beef is the Meat Standards Australia system, which predicts the palatability of individual muscles and of specific cooking methods and is therefore consumer oriented. By contrast, reliable eating-quality-guarantee systems are still lacking in Europe (in spite of individual efforts). As the authors further point out, European consumers seem to be more interested in a direct indication of the healthfulness and quality of beef than in traceability and origin information. Thus, guaranteeing consistent eating quality can have multiple benefits, from more satisfied consumers to the increased profitability of the beef industry and improved competitiveness. In the research of Verbeke et al. (2010), eight focus groups were selected in the capitals of Germany, Spain, France and the UK, and their potential acceptance of a beef eating-quality-guarantee system was studied, with a generally positive outcome. The development of such a system could enable the differentiation of exclusive cuts, offered for a higher price, according to marketing strategies for different target segments.

An interesting finding regarding the acceptance of safety-improving interventions in the beef chain was made by Wezemael et al. (2011). The safety interventions included cattle feed adjustment, hide decontamination, and other safety-improving processing techniques. The study showed that consumers were less inclined to receive such detailed information. Thus, the findings suggest that providing too much detail about safety-improving interventions can actually raise suspicion.

\subsection{Production costs in the beef supply chain}

The recent Agribenchmark study on the cost of production and competitiveness of beef compared the production costs of cow-calf production and beef finishing across the EU, US and Canada (Deblitz and Dhuyvetter, 2013). Whereas the typical American farm practices feedlot farming, EU farms are usually based on silage. It was found that production costs in the EU are higher than in the US (up to twice as high in the EU). As regards beef finishing, production costs for representative US farms are 340 EUR per $100 \mathrm{~kg} \mathrm{CW}$, which is about $20 \%$ - $70 \%$ lower than for representative European farms. In addition, the structure of production costs differs. For US feedlot farms, animal purchases and costs of feedstuffs are very important. For farms based on silage, a large share of the costs is in producing their own feed. Furthermore, American farms have a cost advantage in labour productivity, which is associated with economies of scale and cheaper labour from immigrant workers. On the other hand, the costs of producing grass-fed cattle in US are higher, which is related to higher pasture land costs.

The evolution of producer prices in the EU shows that they remain below estimated production costs. This suggests that the margins from beef production are negative and the existence of direct payments plays an important role in achieving profitability. This is confirmed by the Irish example, which reveals that only $20 \%$ of beef farms are economically viable and $50 \%$ of gross farm output is formed by decoupled farm payments. However, it should be noted that for the farm as a whole, profitability may be still achieved by profits from other farming activities such as dairy, which can cover the losses from beef production.

\subsection{Sustainability aspects of the beef supply chain}

The interconnection between the different aspects of sustainability and their joint effect on all parts of the supply chain suggests that in order to improve the sustainability of beef production, it is necessary to study the whole supply chain.

Three dimensions of sustainability in the beef supply chain are identified in Golini and Kalchschmidt (2011):

* Environmental sustainability concerns waste disposal, which affects almost all stages of the supply chain, but is also strongly regulated for each part of the chain. Next 
to that, an important element of environmental sustainability is the intensity of agricultural production, which can create pollution and degrade natural resources. Nguyen et al. (2010) classifies up to five types of environmental degradation caused by beef production: global warming, acidification, eutrophication, land use changes and nonrenewable energy use.

* Social sustainability mainly refers to food safety and animal well-being, but is also related to worker satisfaction and the social reputation of companies operating in the meat industry. The role of beef supply chains in mountain grassland areas is also part of the social dimension.

* Economic sustainability, in which the major concern is fragmentation in the upper part of the chain and concentration in the bottom part of the chain.

The environmental, economic and social aspects often overlap. One example is animal welfare, which positively affects worker satisfaction from a social point of view and prevents meat deterioration, thereby contributing to economic sustainability. An example of the joint effect of environmental and economic sustainability is the joint management of fodder and breeding activities. It can be noted that players operating in a chain driven by large retailers do not have strong incentives towards higher sustainability, except for social reputation. Furthermore, the research shows that the upstream stages (i.e. the producers) have the largest potential to affect the whole chain because with better fodder quality and animal well-being, costs related to slaughter processes are reduced and it is easier to process meat of high quality. Finally, higher quality meat translates into higher selling prices. Despite this evidence, the upstream players are usually in the least advantageous position for taking action.

$$
\begin{aligned}
& 2 . \quad \text { External factors influencing } \\
& \text { the competitiveness of beef }
\end{aligned}
$$

\subsection{Impact of the Common Agricultural Policy}

The development of the beef sector is to a large extent affected by the Common Agricultural Policy. In line with the intention to move towards a greater market orientation, the Fischler reforms introduced decoupling of direct payments in 2003. The evidence shows that the detachment of direct payments from the quantity of animals slaughtered negatively impacted production profitability. Forewarning of this was already given in the projections of Fabiosa et al. (2006), which argued that the CAP reforms would have their greatest production impact on the beef sector, with a $5 \%$ decline in beef production. In recent literature, these worries were confirmed. For instance, Rezitis and Stavropoulos (2010) proved there were negative effects on production in the case of Greece; a decline in profitability has also been reported in Ireland (Irish Department of Agriculture, 2014). A study by Ihle et al. (2012) found that the 2003 EU agricultural policy reforms significantly impacted price relationships in the EU countries and led to a decrease in the price of calves. The authors further argued that the EU markets are highly integrated, which provides a strong argument against member-state-specific policy actions.

Decoupling has also had an indirect negative effect on beef production through a decline in dairy cow numbers. As regards the relationship with dairy production, the Irish report highlights the problem of cross subsidization of beef to dairy herds - "the price differential between beef from suckler and dairy herds is regarded as too small and does not sufficiently reward farmers for producing quality leaner carcases".

The fear of a drastic decline in suckler cow herds under the decoupling has led to the exemption of decoupling for the specific type of production that EU members will be able to opt for in the new reform, from 2013 onwards. With respect to the future development of the CAP, the abolition of milk quotas in 2015 might stimulate milk production in areas that are competitive for beef production, such as Ireland (Hocquette and Chatellier, 2011).

\subsection{WTO Doha Round Agreement}

Due to the existence of an import tariff on beef (12.8\% of value), internal prices of beef in the EU are higher than international prices. Further liberalization of trade in the Doha Round agreement will thus reduce the domestic price level of beef. It is expected that the tariffs applied on beef imports will be reduced by $70 \%$. According to FAPRI, this could result in a decline in beef prices in Ireland by $27 \%$ and a significant drop in beef production. If beef is designated as a sensitive product, there would be a $9 \%$ decline in Irish cattle prices.

Besides the WTO negotiations, there are two regional trade agreement initiatives that could significantly affect the competitiveness of beef in the EU - the Transatlantic Trade and Investment Partnership (TTIP) and the Mercosur free trade area. 


\subsection{Trade agreement with the US - Transatlantic Trade and Investment Partnership (TTIP)}

According to an independent study by the Centre for Economic Policy Research (Francois et al., 2013), the Transatlantic Trade and Investment Partnership could provide the EU with economic gains of $€ 119$ billion a year once the agreement is fully implemented, and boost the GDP of the EU by $0.5 \%$.

EU-US trade is also important for agriculture. When comparing domestic support and market access levels, it can be concluded that the European market is more protected than the American. According to Grueff and Tangermann (2013), the single commodity transfer for beef is $19.3 \%$ in the EU, whereas in the US it is close to $0 \%$. This is mainly due to high import protection in the EU. The average tariff applied by the US on animal products is $2.4 \%$, whereas in the EU it is $24.3 \%$. For a successful conclusion of the TTIP agreement, import tariffs are going to be significantly reduced, which could represent an opportunity for both the EU and US to increase the volume of trade.

However, the major issues in the TTIP negotiations in beef are the sanitary and phytosanitary (SPS) measures, which have been a source of conflict in the past and have significantly impacted trade between the EU and US. Regarding exports from the US to the EU, a major concern relates to the EU ban on imports of beef produced with hormones (and beta-agonists), which was the subject of a dispute resolved by the WTO in 1999, ruling in favour of the US. It is estimated that the SPS measures may represent up to $70 \%$ of protection when converted to the equivalent tariff rate (Engelbert, 2013). Therefore, there are great expectations from the North American side to tackle the issue of hormone and beta-agonist use in the TTIP negotiations.

If the negotiations are completed successfully, it is expected that they will have a positive effect on European agriculture as a whole; however, for certain meat-producing sectors, the temporal effect could be negative (COM, 2013). This opinion contrasts with the findings of the Agribenchmark study (Deblitz and Dhuyvetter, 2013). The authors estimate that under the SPS conditions of exporting "hormone/beta-agonist-free beef", the prices of US beef would reach the same level as EU domestic prices (since the absence of hormones raises production costs in the US). However, an exact prediction of the cost increase for complying with the SPS rule is unknown. Therefore, it is still possible that imports from the US would increase. In that case, the production systems in Europe that would be most affectedaregrain-fedbeefsystems suchastheSpanish feedlot system. Lower-quality beef originating from a dairy cow herd which is mostly used for minced meat would not be competitive with US exports.

\subsection{Trade agreement with Mercosur}

Negotiations of the EU-Mercosur Association Agreement were resumed in 2010 after a suspension in 2004 due to substantial differences in the trade part of the agreement. Preparations for concluding the agreement are ongoing. Agriculture plays an important role in the Association Agreement with Mercosur because the EU, being a net importer of agricultural products from Mercosur, accounts for more than $50 \%$ of Mercosur exports of agricultural products.

According to an impact assessment study prepared for the European Commission (Kirkpatrick and Gerge, 2009), under the scenario of full trade liberalization between the EU and Mercosur, meat production would increase significantly in Latin American countries, with the largest impacts in Brazil $(+50 \%)$ and Paraguay $(+70 \%)$. It is predicted that increased imports of beef and chicken would raise pressure on EU producers. According to the Copa-Cogeca Report (2011), the direct losses due to increased imports would reach $€ 16$ billion, and indirect losses from lower beef prices would be around $€ 9$ billion in the EU beef sector alone. Although these estimates could be exaggerated, according to DG Trade, there could be a negative social impact related to a decline in rural employment, particularly in marginal areas. Furthermore, there are also strong environmental concerns, since a significant increase in meat production in Latin American countries would result in adverse land use changes connected to a loss in global biodiversity, increased deforestation and a visible rise in emissions levels.

\subsection{Future prospects, opportunities and threats to the $\mathrm{EU}$ beef sector}

Based on the supply chain analysis and the external factors that affect the beef sector, some opportunities and threats were identified.

\section{Opportunities for improving the competitiveness of beef in the $E U$ :}

\section{- Focus on science and innovation}

There are various opportunities that can be explored in the domain of science and innovation, of which the most important areas are animal genetics 
and nutrition efficiency. For instance, there are potential solutions in the form of technological innovations that monitor animal health and reproductive status using biosensors. Research potential also exists in the optimization of digestive and metabolic functions in order to improve nutrition efficiency and thereby reduce production costs. It was found that genetics (improving feed conversion, reducing veterinary and medical costs) enables producers to reduce their production costs by 223 pounds per cow.

More efforts should be made to understand the interaction of nutrition, climatic constraint and genotype. Finally, another area of attention should be the development of precision livestock farming in Europe.

- Better coordination and involvement of producers in the beef supply chain

Scientific contributions are insufficient if they are not implemented in a coordinated way. According to the experience of the British value chain initiative, the use of similar genetics and feeding practices that appeal to target consumer segments are the critical factors in the success of the value chain.

It has also been shown that vertical coordination can reduce transaction costs and thereby improve the share of added value that accrues to producers. Furthermore, collaborative supply chains help to reduce price risks. It is therefore important to support collaborative efforts at the policy level.

\section{- Improvement of logistics systems}

There are still possibilities for improving logistics systems. First, more careful handling of animals can significantly reduce their stress. Second, using route optimization methods can reduce transport time and emissions. Developing smaller-scale slaughterhouses would be another recommendation based on the empirical evidence.

- Developing more advanced quality-guarantee systems

From the consumer's point of view, there is great interest in information about health content and meat quality; however, eating-quality systems comparable to MSAS are still lacking. For producers, this could mean better pricing of the exclusive parts of beef and would allow them to apply different marketing strategies. Higher price differentials between suckler and dairy beef would also motivate farmers to produce quality leaner carcases.
Research evidence also shows that there could be too many quality signs currently in use, which causes great confusion and mistrust among consumers. Therefore, unification of the quality signs should be discussed.

\section{Factors threatening the competitiveness of beef in the $E U$}

\section{- Trade liberalization}

Given that the EU beef market is highly protected by both tariff and non-tariff measures, further liberalization will lead to open competition with external countries, which could seriously threaten the competitiveness of domestic beef. This mainly refers to the Mercosur Association Agreement, because the production costs for beef are higher in the EU than in Latin American countries. As for the US, the threat is lower due to the increased costs for beef produced without the use of hormones and beta-agonists.

\section{- Climate change}

According to McAlpine et al. (2009), beef consumption is a major driver of regional and global change. With increasing globalization, tropical forests are being replaced by grazing land in Brazil and other parts of Latin America, which substantially contributes to greenhouse gas (GHG) emissions and loss of biodiversity. These findings call for abandoning subsidies for beef production and supporting the reduction of beef in consumer diets. Therefore, in order to achieve sustainability in beef production, more research should be done to reduce GHGs, for instance by minimizing waste and through carbon sequestration.

- Competition with other agricultural
commodities

Beef is a competitor of milk and grains. Regarding the abolishment of milk quotas, it is expected that producers will be motivated to orient towards milk production at the expense of beef. The recently higher prices for grain in turn raise competition for pasture production, which is replaced by cultivating crops instead of pastures. These trends can be observed mostly in Latin America, where feedlot production has been increasingly replacing traditional grasslands.

The above-mentioned threats suggest that it is important to better target direct payments to beef producers, given the low profitability of production in the EU. In light of the sustainability concerns, it is important to maintain and support a focus on environmental and territorial services. 


\section{Conclusion}

The European Union is the third largest producer of beef in the world. The future prospects of beef production in the EU will be driven by the effects of globalization and trade liberalization. On one hand, increasing demand for beef in developing countries could act in favour of the further expansion of beef production; on the other hand, climate change concerns could act against it.

European producers of beef are facing tougher market competition due to CAP reforms and further trade liberalization, which will open European markets to important players such as the United States, Canada and the Mercosur countries. To turn these potential threats into opportunities, strategies for increasing competitiveness are necessary. In this study, it is shown that investing in collaborative supply chains can improve the disadvantaged position of beef producers with the least power in the supply chain. In addition, several opportunities that could be further explored come from the domain of science and innovation. Examples include animal genetics, nutritional science and greater exploration of possibilities for improving the well-being of animals and optimizing logistical routes.

Nevertheless, in view of the increasing liberalization efforts and high threat of major beef competitors such as Brazil or USA, the realistic vision is that EU beef sector be maintained at a self-sufficient level with a special accent on environmental sustainability and high consumer quality. In this respect, the direct payments can play an important role in stimulating beef production conditional to complying with strict environmental standards.

All these ideas lead to improved animal welfare, which is a central issue and is at the intersection of all sustainability dimensions of livestock farming systems.

\section{Corresponding author:}

Ing. Zuzana Smeets Křistková, Ph.D.

Department of Economics of Agriculture, Faculty of Economics and Management Czech University of Life Sciences, Kamýcká 129, 16521 Prague 6-Suchdol, Czech Republic

Phone: 224382057,E-mail: kristkova@pef.czu.cz

\section{References}

[1] Angulo, A., Gil, J. Risk perception and consumer willingness to pay for certified beef in Spain. Food Quality and Preference. 2007, Vol. 18, p. 1106-1117. ISSN: 0950-3293.

[2] Beef Magazine.com. Argentina provides a lesson in how to ruin a beef industry. [Online] Available: http://beefmagazine.com/beef-exports/argentina-provides-lesson-how-ruin-beef-industry [Accessed: Sept 26, 2013].

[3] Bulitta, F. S., Bosona, T., Gebresenbet G. Modelling the dynamic response of cattle heart rate during loading for transport. Australian journal of agricultural sciences. 2011, Vol. 2, No. 3, p. 66-73. ISSN 0004-9409.

[4] Copa Cogeca. The agricultural impact of an EU-Mercosur agreement. Report prepared by CopaCogeca, 2011. [Online] Available online: www.copa-cogeca.be/Download.ashx?ID=941661 [Accessed: Dec 10, 2013].

[5] Deblitz, C., Dhuyvetter, K. Costs of production and competitiveness of beef production in Canada, the US and the EU. Agribenchmark Working Paper 2013/5, 2013. [Online] Available: http://www.agribenchmark.org/fileadmin/Dateiablage/B-Beef-and-Sheep/Working-Paper/bs-05USEU-neu.pdf [Accessed: Jan 4, 2014].

[6] Directorate-General for Agriculture and Rural Development. Agriculture in the European Union Statistical and Economic Information Report 2012, December 2012. [Online] Available: http://ec.europa.eu/agriculture/statistics/agricultural/index_en.htm [Accessed: January 15, 2014].

[7] Engelbert, T., Brockmeier, M., Francois, J. The role of agriculture in the EU-US free trade agreement - Empirical evidence based on a joint econometric-CGE modelling approach. Paper presented at the ETSG 2013 Birmingham Fifteenth Annual Conference, 12-14 September 2013, University of Birmingham. 
[8] European Commission $\{\operatorname{COM}(2013) 136$ final $\}$. Impact Assessment Report on the future of EU-US trade relations. [Online] Available: http://trade.ec.europa.eu/doclib/docs/2013/march/ tradoc_150759.pdf [Accessed: Sep 15, 2014].

[9] European Parliament. EU-Member States in Agri-Food World Markets: Current Competitive Positions and Perspectives, 2014. [Online] Available: http://www.europarl.europa.eu/RegData/ etudes/STUD/2014/514006/IPOL_STU\%282014\%29514006_EN.pdf [Accessed: Nov 20, 2014].

[10] Eurostat Economic Accounts for Agriculture. Values at constant 2005 prices. 2013. [Online] Available: http://epp.eurostat.ec.europa.eu/portal/page/portal/agriculture/data [Accessed: Feb 25, 2014].

[11] Fabiosa, J., Beghin, J., Dong, F., El Obeid, A., Fuller, F., Matthey, H., Tokgöz, S., Wailes, E. The impact of the European enlargement and CAP reforms on agricultural markets: Much ado about nothing? Poster paper prepared for presentation at the International Association of Agricultural Economists Conference, Gold Coast, Australia, August 12-18, 2006.

[12] Francis, M., Simmons, D., Bourlakis, M. Fearne, A. Identifying the determinants of value in the U.K. red meat industry: A value chain analysis approach. Journal on Chain and Network Science. 2003, Vol. 3, No. 2, p. 109-121. ISSN 1569-1829.

[13] Francois, J., Manchin, M., Norberg, H., Pindyuk, O., Tomberger, P. Reducing transatlantic barriers to trade and investment: An economic assessment. Centre for Economic Policy Research, Final Project Report, March 2013. [Online] Available: http://trade.ec.europa.eu/doclib/docs/2013/march/ tradoc_150737.pdf [Accessed: Jan 21, 2014].

[14] Gebresenbet, G., Bosona, T. Logistics and supply chains in agriculture and food. Chapter in Groznik, A. and Xiong Yu: Pathways to supply chain excellence, InTech. March 2012, p. 208. ISBN 978-953-51-0367-7.

[15] Golini, R., Kalchschmidt, M. Sustainability in the food supply chain: Evidence from the Italian beef industry. In Correa, Henrique; Nelis, Mir (Eds.), Proceedings of the 22nd POMS Annual Conference, 2011. [Online] Available: http://hdl.handle.net/10446/25454 [Accessed: March, 2015].

[16] Grueff, J., Tangermann, S. Achieving a successful outcome for agriculture in the EU-U.S. Transatlantic Trade and Investment Partnership agreement. International Food \& Agricultural Trade Policy Council. Discussion paper, February 2013. [Online] Available: http://www.agritrade.org/ Publications/documents/FINAL_US_EU_FTA_fordistribution.pdf [Accessed: April 24, 2014].

[17] Hocquette, J. F., Chatellier, V. Prospects for the European beef sector over the next 30 years. Animal Frontiers. October 2011, Vol. 1, No. 2, pp. 20-28. ISSN 2160-6056.

[18] Hofwegen, G., Becx, G., Broek, J. Drivers for competitiveness in agri-food chains: A comparative analysis of $10 \mathrm{EU}$ food product chains. A report for the EUMercoPol project - WP4, 2005.

[19] Ihle, R., Brummer, B., Thomson, S. Structural change in European calf markets: Decoupling and bluetongue disease. European Review of Agricultural Economics. 2012, Vol. 39, p. 157-179. ISSN 1464-3618.

[20] Institute of Agricultural Economics and Information (UZEI). Impact of global and European markets for milk, beef, pork, poultry and lamb on the Czech commodity market in 2013 (in Czech: „Vliv světového a evropského trhu mléka, hovězího, vepřového, drůbežího a skopového masa na trh komodit v ČR v roce 2013“). Report 2 (4222), September 2013.

[21] Irish Ministry of Agriculture. Meat Industry Ireland: 2020 Strategy - Beef Sector, submission from Meat Industry Ireland. April 2010, [Online] Available: http://www.agriculture.gov.ie [Accessed: Jan. 15, 2014].

[22] Kirkpatrick, C., George, C. Trade sustainability impact assessment of the association agreement under negotiation between the European Community and Mercosur. University of Manchester, Report prepared for the European Commission, 2009. [Online] Available: http://trade.ec.europa.eu/ doclib/docs/2009/april/tradoc_142921.pdf [Accessed:March 5,2013]. 
[23] McAlpine, C. A., Etter, A., Fearnside, P. M., Seabrook, C. L., Laurance, W. F. Increasing world consumption of beef as a driver of regional and global change: A call for policy action based on evidence from Queensland (Australia), Colombia and Brazil. Global Environmental Change. 2009, Vol. 19, p. 21-33. ISSN 09593780.

[24] Nguyen, T. L. T., Hermansen, J. E., Mogensen, L. Environmental consequences of different beef production systems in the EU. Journal of Cleaner Production. 2010, Vol. 18, p. 756-766. ISSN: 0959-6526

[25] OECD-FAO. Agricultural Outlook Database, 2014. [Online] Available: http://stats.oecd.org/Index. aspx?DataSetCode=HIGH_AGLINK_2012 [Accessed: April 20, 2014].

[26] Revoredi-Giha, C., Leat, P. Collaborative supply chain initiatives as devices to cope with income variability in the Scottish red meat sector. Paper prepared for a presentation at EAAE Seminar, Warsaw, 2008.

[27] Rezitis, A., Stavroopoulos, K. Modelling beef supply response and price volatility under CAP reforms: The case of Greece. Food Policy. 2010, Vol. 35, p. 163-174. ISSN: 0306-9192.

[28] Roest, K., Jongeneel, R., Dillen, K., Winsten, J. Cross-compliance and competitiveness in the European beef and pork sectors. Paper presented for the 109th EAAE Seminar, November 20-21, Italy, 2008.

[29] Rumánková, L. Examination of market structure in selected livestock agri-food chains in the Czech Republic. Acta univ. agric. et silvic. Mendel. Brun. 2012, Vol. LX, No. 7, p. 243-258. ISSN 1211-8516

[30] Safefood. A review of the beef food chain, February 2008. [Online] Available: http://www. safefood.eu/SafeFood/media/SafeFoodLibrary/Documents/Publications/Research\%20Reports/ Safefood_8202_A5_Beef_Summary-20(2).pdf [Accessed: Jan. 5, 2014].

[31] Spencer, S. Price determination in the Australian food industry: A report, Australian government, Department of Agriculture, Fisheries and Forestry, Canberra, 2004. [Online] Available: http://www.daff.gov.au/_data/assets/pdf_file/0003/182442/food_pricing_report.pdf [Accessed: Jan. 12, 2014].

[32] The Beef Site: What are the prospects for imports from Brazil? [Online] Available: http://www.thebeefsite.com/articles/3119/what-are-the-prospects-for-imports-from-brazil [Accessed: March 12, 2012].

[33] Uddin, M. N., Islam, N., Quaddus, M. Supply chain performance in the Australian beef industry. Department of Agriculture and Food, 2011. ISBN 978-0-9807334-2-6.

[34] United States Department of Agriculture, Foreign Agricultural Service - Production, Supply and Distribution Online Database (USDA FAS-PSD). [Online] Available: http://apps.fas.usda.gov/ psdonline/psdQuery.aspx [Accessed: Jan 10, 2014].

[35] USDA. Livestock and poultry: Global markets and trade, November 2013. [Online] Available: http://apps.fas.usda.gov/psdonline/circulars/livestock_poultry.pdf [Accessed: Jan 5, 2014].

[36] Value Chain Management Centre. Learning from the British beef industry - research findings, 2011. [Online] Available: http://vcm-international.com/wp-content/uploads/2013/04/Learning-From-TheUK-Beef-Industry.pdf [Accessed: Jan 3, 2014].

[37] Verbeke, W., Wezemael, L., Barcellos, M., Kugler, H., Hocquette, J., Ueland, Ø., Grunert, K. G. European beef consumer interest in a beef eating-quality guarantee. Insights from a qualitative study in four EU countries. Appetite, 2010, Vol. 54, p. 289-296. ISSN: 0195-6663.

[38] Wezemael, L., VeRbeke, W., Kugler, J., Shcolderer, J. European consumer acceptance of safety-improving interventions in the beef chain. Food control. 2011, Vol. 22, p. 1776-1784. ISSN: 0956-7135. 